\title{
LEGALITAS PENGGUNAAN VIRTUAL OFFICE SEBAGAI KANTOR ADVOKAT
}

\author{
Oleh: \\ Ni Kadek Ratna Jayanti ${ }^{1}$
}

\begin{abstract}
Virtual office is a joint office equipped with physical facilities and human resources facilities. Virtual office is supported with internet facility, call center, receptionist, workspace, and technology-based meeting room. Advocates can use virtual office as an office in providing legal services to the public. In this study there are two problems that can be formulated that is 1) how is the legal relationship between the owner of a virtual office with an advocate who uses a virtual office as an advocate office? 2) How can a virtual office place be the domicile of an advocate's office? This study is a normative legal research that examines the empty norm of virtual office. This condition will complicate the determination of domicile of a business entity. Legal material consists of primary legal materials and secondary legal materials collected through library studies. The analysis is done qualitatively. The legal relationship between a virtual office owner and an advocate who using a virtual office as an advocate's office is based on a lease agreement. Virtual office agreement object used as an advocate's office. The virtual office space may be the seat of an advocate's office. Legality of advocates is determined by individual qualifications. In Act No. 18 of 2003 on Advocates does not regulate the requirements of the advocate's office as the basis of legality as an advocate. The virtual office address can be used as the domicile of the advocate office.
\end{abstract}

Keywords: legality, virtual office, advocate.

\begin{abstract}
Abstrak
Virtual office adalah kantor yang bersama yang dilengkapi dengan fasilitas fisik dan fasilitas sumber daya manusia. Virtual office didukung dengan fasilitas internet, call center, resepsionis, ruang kerja, dan ruang pertemuan berbasis teknologi. Advokat dapat menggunakan virtual office sebagai kantor dalam memberikan jasa hukum kepada masyarakat. Dalam penelitian ini ada dua permasalahan yang dapat dirumuskan yakni 1) bagaimanakah hubungan hukum antara pemilik virtual office dengan advokat yang menggunakan virtual office sebagai kantor advokat? 2) Bagaimanakah tempat kedudukan virtual office dapat menjadi tempat kedudukan kantor advokat? Penelitian ini merupakan penelitian yuridis normative yang mengkaji mengenai kekosongan norma mengenai virtual office. Kondisi ini akan menyulitkan legalitas penentuan domisili suatu badan usaha. Bahan hukum terdiri dari bahan hukum primer dan bahan hukum sekunder yang dikumpulkan melalui studi kepustakaan. Analisis dilakukan secara

1 Program Studi Magister Ilmu Hukum, Fakultas Hukum Universitas Udayana Denpasar, Bali, email: karaj_y@yahoo.co.id.
\end{abstract}


kualitatif. Hubungan hukum antara pemilik virtual office dengan advokat yang menggunakan virtual office sebagai kantor advokat didasarkan pada perjanjian sewa menyewa. Objek perjanjian virtual office yang digunakan sebagai kantor advokat. Tempat kedudukan virtual office dapat menjadi tempat kedudukan kantor advokat. Legalitas advokat ditentukan oleh kualifikasi individu. Dalam Undang-Undang Nomor 18 tahun 2003 tentang Advokat tidak mengatur persyaratan mengenai kantor advokat sebagai dasar legalitas sebagai advokat. Alamat virtual office dapat digunakan sebagai domisili kantor advokat.

Kata kunci: legalitas, virtual office, advokat.

\section{PENDAHULUAN}

Virtual office atau kantor virtual merupakan sebuah ruang kerja yang beroperasi dengan memanfaatkan dunia maya. Keberadaan virtual office pertama didirikan oleh Ralph Gregory pada tahun 1994 dengan mendirikan "Virtual Office, Inc.", di Boulder, Colorado. Seorang pebisnis yang ingin membuat kantor tidak perlu membuat bangunan fisik sendiri. Pebisnis hanya cukup menyewa virtual office untuk memulai bisnisnya. Penyewa dapat melakukan pekerjaan yang diperlukan secara profesional atau secara pribadi tanpa memiliki "fisik" lokasi usaha. Kantor virtual ini menggunakan aplikasi layanan perkantoran dengan format virtual, baik dalam bentuk surat menyurat dengan alamat email, fax, telepon, dan jaringan internet lainnya. Kehadiran virtual office tidak dapat dilepaskan dari revolusi teknologi dan informasi yang berkembang sedemikian pesat dalam kegiatan bisnis.

Pemilik virtual office akan membangun sebuah gedung di lokasi bisnis yang strategis, lalu menyewakan kantornya kepada beberapa pebisnis untuk melakukan kegiatan usaha. Operasional perkantoran seperti lobby, jasa resepsionis, surat-menyurat, ruang rapat bisnis meeting space, internet broadband, fax, printer fotokopi, fitur telepon tingkat lanjut, call center, conference call, live receptionist virtual, video conferencing, dapur dan lain-lain disediakan oleh pemilik virtual office. Fasilitas tersebut dapat digunakan oleh penyewa virtual office. Penggunaan istilah virtual office memang lebih sederhana apabila disebut sebagai kantor bersama. Virtual office pada umumnya digunakan dalam kegiatan home industri barang/jasa, toko online, konsultan, akuntan, kamar dagang, kantor advokat, praktik dokter, apotek, broker saham dan lain-lain. Kehadiran virtual office dalam dunia usaha dilakukan untuk menghemat biaya pembuatan kantor, namun penyewa mendapatkan alamat kantor yang bergengsi dengan segala fasilitas eksklusif yang dapat dimanfaatkan oleh penyewa. 
Para advokat ${ }^{2}$ dapat menggunakan virtual office untuk memberikan layanan jasa hukum. Dalam memulai praktek jasa hukum, seorang advokat harus memiliki modal untuk membuat kantor hukum. Lokasi kantor hukum dirasakan sangat penting untuk menentukan prestise advokat itu sendiri. Di beberapa daerah, seperti Jakarta, advokat tidak dapat membuka kantor advokat di rumahnya. Ketentuan mengenai kawasan perkantoran diatur dalam ketentuan mengenai zonasi kawasan bisnis. Hal ini berarti, seorang advokat harus menyiapkan anggaran yang cukup banyak untuk menyewa kantor di lokasi yang strategis dan mendanai infrastruktur kantor. Apabila dana untuk infrastruktur kantor tidak memadai, biasanya seorang advokat akan memilih café atau restoran untuk bertemu dengan klien. Kondisi ini menjadi peluang bagi pemilik virtual office untuk menyewakan kantor miliknya kepada advokat, lengkap dengan layanan resepsionis, alat surat-menyurat, ruang meeting, ruang presentasi dan berbagai fasilitas lainnya.

Prospek bisnis penyewaan virtual office sangat besar, mengingat sejumlah daerah telah mengeluarkan peraturan daerah tentang larangan penggunaan tempat tinggal sebagai

2 Menurut Pasal 1 angka 1 Undang-undang Nomor 18 Tahun 2003 tentang Advokat dinyatakan "Advokat adalah orang yang berprofesi memberi jasa hukum, baik di dalam maupun di luar pengadilan yang memenuhi persyaratan berdasarkan ketentuan Undangundang ini." tempat usaha. Pilihan untuk menyewa virtual office tentu dapat menekan biaya yang akan dikeluarkan dibandingkan apabila seorang advokat harus membuat kantor sendiri. Di Indonesia, legalitas penggunaan virtual office belum diatur dengan tegas, mengingat perbuatan hukum ini baru berkembang di Indonesia. Dalam pengurusan SIUP dan tanda daftar perusahaan, setiap pengusaha wajib membuat Surat Keterangan Domisili Badan Usaha (SKDBU). Undang-Undang yang mengatur mengenai virtual office memang belum ada. Untuk mengatasi kekosongan hukum ini, pemerintah telah mengeluarkan surat edaran yang sebelumnya melarang penggunaan alamat virtual office sebagai tempat domisili badan usaha.

Dalam perkembangannya, dikeluarkan Surat Edaran Nomor 41/ SE/Tahun 2015 tanggal 2 November 2015 tentang Surat Keterangan Domisili Badan Usaha yang Berkantor Virtual yang memperbolehkan pembuatan Surat Keterangan Domisili Badan Usaha (SKDBU) pada Badan Usaha yang berkantor virtual (virtual office). Sampai saat ini, surat edaran tersebut masih bersifat sementara mengingat belum adanya payung hukum yang mengatur mengenai virtual office. Pengaturan mengenai virtual office terutama terkait dengan domisili atau tempat kedudukan badan usaha sangat penting, mengingat ketentuan mengenai tempat kedudukan suatu kantor hukum akan menentukan 
tempat dilakukannya perbuatan hukum dan merupakan domisili pilihan dari para klien yang memilih alamat kantor hukum tersebut.

Dalam penelitian ini ada dua permasalahan yang dapat dirumuskan yakni 1) bagaimanakah hubungan hukum antara pemilik virtual office dengan advokat yang menggunakan virtual office sebagai kantor advokat? 2) Bagaimanakah tempat kedudukan virtual office dapat menjadi tempat kedudukan kantor advokat? Penelitian mengenai "Legalitas Penggunaan Virtual Office Sebagai Kantor Advokat" adahah penelitian baru yang belum pernah ditulis sebelumnya oleh peneliti lain. Ada beberapa penelitian yang terkait dengan penelitian ini diantaranya:

1. Integrasi Aplikasi Kolaborasi Untuk Kantor Virtual oleh Basuki Winoto. Penelitian ini ditulis dalamkajianteknikinformasikan. Dalam penelitian tersebut ada beberapa permasalahan yakni bagaimanakah dukungan kolaborasi dengan layanan yang lengkap dapat mewujudkan sistemkantorvirtual,infrastruktur pendukung, integrasi aplikasi kolaborasi dan aspek formalisasi aktifitas dalam organisasi? ${ }^{3}$ Penelitian ini memberikan gambaran mengenai kinerja virtual office.

3 Basuki Winoto, 2015, Integrasi Aplikasi Kolaborasi Untuk Kantor Virtual, Prosiding Seminar Nasional Aplikasi Teknologi Informasi 2005 (SNATI 2005), Yogyakarta, 18 Juni 2005, hlm. 1.
2. Penegakan Kode Etik Profesi Advokat dalam Pendampingan Klien Perkara Pidana Korupsi oleh Franciscus Xaverius Raditya Wicaksono. Dalam penelitian ini dikaji tentang permasalahan bagaimana penegakan terhadap pelanggaran kode etik profesi Advokat yang mendampingi klien perkara pidana korupsi? ${ }^{4}$ Penelitian ini meneliti mengenai advokat sedangkan dalam penelitian penulis, dikaji tentang legalitas virtual office bagi advokat

3. Peran Advokat salam Pendampingan Hukum, oleh Sahuri Lasmadi. Penelitian ini membahas mengenai bagaimana peran advokat dalam pendampingan hukum? Dan apakah kendala yang di hadapi advokat dan solusinya? Penelitian ini membahas mengenai profesi advokat dalam penegakan hukum pidana. $^{5}$

Tujuan dalam penelitian ini adalah sebagai berikut: Tujuan umum penelitian ini adalah untuk menganalisis legalitas penggunaan virtual office sebagai kantor advokat. Tujuan khusus penelitian adalah sebagai berikut:

4 Franciscus Xaverius Raditya Wicaksono, 2014, Penegakan Kode Etik Profesi Advokat dalam Pendampingan Klien Perkara Pidana Korupsi, Jurnal Hukum Fakultas Hukum Universitas Atma Jaya Yogyakarta, Yogyakarta, hlm. 1.

5 Sahuri Lasmadi, 2014, Peran Advokat salam Pendampingan Hukum, Jurnal Inovatif, Volume VII Nomor II Mei 2014, Jambi, hlm. 1. 
1) Untuk menganalisis hubungan hukum antara pemilik virtual office dengan advokat yang menggunakan virtual office sebagai kantor advokat dan

2) Untuk menemukan legalitas tempat kedudukan virtual office menjadi tempat kedudukan kantor advokat.

\section{METODE PENELITIAN}

Jenis penelitian ini adalah penelitian yuridis normatif. Fokus kajian hukum normatif adalah inventarisasi asas-asas dan doktrin hukum, hukum positif, penemuan hukum dalam suatu perkara, sistematik hukum, perbandingan hukum, taraf sinkronisasi hukum, dan sejarah hukum. ${ }^{6}$ Kajian dilakukan terhadap kekosongan norma yang mengatur mengenailegalitas virtualoffice sebagai kantor advokat. Pendekatan yang digunakan dalam penelitian ini adalah pendekatan perundang-undangan yang mengkaji mengenai ketentuan hukum perdata, hukum dagang dan undang-undang terkait. Selain itu, penelitian ini juga menggunakan pendekatan konsep hukum yakni konsep hukum perusahaan, advokat dan domisili. Pendekatan-pendekatan tersebut dilakukan untuk menganalisis permasalahan yang dibahas dalam penelitian ini.

Bahan hukum terdiri dari bahan hukum primer yakni KUH Perdata,

6 Bambang Sunggono, 1997, Metodologi Penelitian Hukum, Raja Grafindo Persada, Jakarta, hlm. 83-102
KUH Dagang, dan Surat Edaran Nomor 41/SE/Tahun 2015 tanggal 2 November 2015 tentang Surat Keterangan Domisili Badan Usaha yang Berkantor Virtual serta bahan hukum sekunder yakni literatur yang digunakan dalam penelitian ini. Bahan hukum dikumpulkan melalui studi kepustakaan. Teknis pengolahan dan analisis bahanhukum dilakukan dengan teknik deskripsi, teknik argumentasi dan teknik evaluasi. Analisis dilakukan secara kualitatif. Bahan hukum yang telah diolah disajikan secara deskriptif analitis. Cara analisis deskriptifanalitis memberikan gambaran mengenai subjek dan objek penelitian yang diikuti dengan pemaparan mengenai hasil penelitian yang dilakukannya. ${ }^{7}$ Dengan demikian, akan diperoleh jawaban mengenai legalitas penggunaan virtual office sebagai kantor advokat.

\section{HASIL DAN PEMBAHASAN}

3.1 Hubungan Hukum Antara Pemilik Virtual Office dengan Advokat yang Menggunakan Virtual Office Sebagai Kantor Advokat

Virtual office merupakan terminologi baru dalam bidang hukum perusahaan. Pengaturan mengenai virtual office hingga saat ini belum ada. Dalam KUH Perdata, KUH Dagang dan Undang-Undang di bidang keperdataan lainnya tidak mengatur

7 Mukti Fajar dan Yulianto Achmad, 2010, Dualisme Penelitian Hukum Normatif dan Empiris, Pustaka Pelajar, Yogyakarta, hlm.183. 
mengenai virtual office. Hal ini merupakan hal yang wajar mengingat keberadaan virtual office itu sedari baru berkembang di dunia mulai tahun 1994, sedangkan di Indonesia sendiri baru berkembang beberapa tahun belakangan ini. Merujuk pada konsep rechststaat atau negara hukum yakni negara yang dalam penyelenggaraan pemerintahannya berdasarkan pada prinsip-prinsip hukum ${ }^{8}$, maka pengaturan mengenai virtual office perlu dibuat secara khusus.

Konsep virtual office hampir sama dengan penyewaan kantor bersama, hanya saja dalam penyewaan virtual office, pemilik tidak hanya menyediakan fasilitas fisik saja, namun juga fasilitas sumber daya manusia yang dilakukan dengan sangat professional. Pemilik virtual office mempekerjakan resepsionis dan layanan call center yang bertugas menjawabsetiaptelepondanpertanyaan secara langsung. Pengiriman surat ke alamat virtual office akan disampaikan oleh resepsionis kepada kantor yang dimaksud. Apabila surat disampaikan dalam bentuk surat elektronik, maka resepsionis akan meneruskan email tersebut kepada yang dituju. Gedung virtual office juga dilengkapi dengan petugas administrasi hingga petugas kebersihan dan keamanan yang bekerja dengan jam kerja tertentu.

8 IDewa Gede Atmadja, 2010, Hukum Konstitusi Problematika Konstitusi Indonesia Sesudah Perubahan UUD 1945, Setara Press, Malang, hlm. 158.
Hubungan hukum adalah hubungan yang menimbulkan akibat secara hukum. Hubungan hukum antara pemilik virtual office dengan advokat yang menggunakan virtual office sebagai kantor advokat adalah perbuatan sewa-menyewa yang dilegitimasi dengan perjanjian sewamenyewa. Menurut Abdulkadir Muhammad,perbuatansewa-menyewa meliputi lima unsur, yaitu persetujuan, penyerahan bendasewaan, pembayaran uang sewa, waktu sewa dan persyaratan sewa-menyewa, yaitu:

a. Persetujuan adalah perbuatan yang menyatakan tercapainya kesepakatan diantara para pihak, yakni pihak yang menyewakan dengan pihak penyewa perihal benda sewaan, harga atau uang sewa, waktu sewa dan persyaratan sewa-menyewa lainnya.

b. Penyerahan yakni suatu perbuatan hukum dengan maksud mengalihkan hak penguasaan benda sewaan dari pihak yang menyewakan kepada pihak penyewa untuk menikmati hak atas benda yang disewakan tersebut.

c. Pembayaran uang sewa adalah suatu kontra prestasi berupa pemberian sejumlah uang dari penyewa kepada pihak yang menyewakan atas benda yang dikuasai penyewa tersebut.

d. Waktu sewa merupakan ukuran lamanya atau jangka waktu 
berlangsungnya sewa-menyewa. e. Persyaratan sewa-menyewa adalah ketentuan-ketentuan yang telah disepakati bersamasama antara pihak yang menyewakan dengan penyewa untuk memungkinkan perolehan hak dan pemenuhan kewajiban diantara para pihak. ${ }^{9}$

Perbuatan sewa-menyewa dilakukan oleh pemilik virtual office sebagai pihak yang menyewakan dan advokat sebagai pihak penyewa atas benda sewaan berupa virtual office yang digunakan sebagai advokat untuk membuka kantor hukum. Perbuatan hukum tersebut dituangkan dalam perjanjian sewa-menyewa. Perjanjian menurut Johannes Ibrahim dan Lindawaty Sewu, merupakan suatu tulisan yang memuat janji yang dibuat olehpara pihak secara lengkap dimana dalam perjanjian tersebut memuat ketentuan-ketentuan dan persyaratanpersyaratan. Perjanjian memiliki fungsi sebagai alat bukti tentang adanya seperangkat kewajiban. ${ }^{10}$ Isi yang dimuat dalam perjanjian itu yang akan dijadikan dasar bagi hakim apabila di kemudian hari terjadi permasalahan hukum" 11 Kewajiban tersebut timbul dari adanya perjanjian sewa-

9 Abdulkadir Muhammad, 2014, Hukum Perdata Indonesia, Citra Additya Bakti, Bandung, hlm. 346.

10 Johannes Ibrahim dan Lindawaty Sewu, 2007, Hukum Bisnis Dalam Persepsi Manusia Modern, Refika Aditama, Bandung, hlm. 43

11 H. Salim HS, H. Abdullah dan Wiwiek Wahyuningsih, 2008, Perancangan Kontrak \& Memorandum of Understanding ( $M o U)$, Sinar Grafika, Jakarta,. hlm. 23-24. menyewa, baik kewajiban pihak yang menyewakan dan pihak penyewa.

Perjanjian sewa-menyewa didasarkan atas asas umum dalam hukum perjanjian yakni asas kebebasan berkontrak. Asas kebebasan berkontrak atau freedom of contract principle mengajarkan bahwa para pihak secara hukum bebas untuk menentukan hal-hal yang ingin mereka uraikan dalam perjanjian atau kontrak yang dibuatnya. Apabila mereka sudah menandatangani kontrak maka para pihak sudah tidak bebas lagi, melainkan sudah terikat kepada hal apa saja yang telah disebutkan dalam kontrak tersebut. ${ }^{12}$ Berdasarkan asas kebebasan berkontrak maka objek sewa-menyewa berupa virtual office tidak dilarang menurut hukum. Seseorang bebas untuk memilih menyewa bangunan gedung fisik ataupun gedung virtual sebagai kantor untuk kegiatan usaha. Kebebasan tersebut hanya dibatasi dengan itikad baik. Prinsip itikad baik dalam pelaksanaan perjanjian ini mengamanatkan agar para pihak menafsirkan perjanjian itu berdasarkan keadilan dan kepatutan. ${ }^{13}$

Seorang advokat dapat menyewa satu blok virtual office dan memanfaatkan semua fasilitas virtual office dengan biaya yang cukup murah. Biaya sewa dibayarkan sesuai dengan perjanjian sewa-menyewa dengan model pembayaran bulanan

12 Munir Fuady, 2014, Konsep Hukum Perdata, Rajawali, Jakarta, hlm. 181.

13 Handri Raharjo, 2009, Hukum Perjanjian di Indonesia, Buku Kita, Jakarta, hlm. 58-59. 
atau tahunan. Harga yang ditawarkan untuk satu blok virtual office mulai Rp 400.000,00. Biaya tersebut tentu sangat ringan dibandingkan dengan membuat kantor sendiri di lokasi bisnis yang mengharuskan advokat menyewa kantor dan melengkapi fasilitas-fasilitasnya. Sebagai seorang penyewa, maka advokat memiliki hak penguasaan atas virtual office, termasuk menggunakan alamat virtual office sebagai tempat kedudukan kantor advokat.

\subsection{Legalitas Tempat Kedudukan Virtual Office Menjadi Tempat Kedudukan Kantor Advokat}

Tempat kedudukan adalah landasan domisili komersial (commercialdomicile)bagiperusahaan. Domisili tersebut sangat penting bagi perusahaan untuk memastikan kegiatan komersial yang dilakukannya. Tempat kedudukan menjadi tempat utama (principalplace)bagiperusahaan untuk mengatur pelaksanaan maksud dan tujuan serta kegiatan usaha Perseroan sebagaimana yang tercantum dalam anggaran dasar dan anggaran rumah tangga. Permasalahan hukum terjadi dimana masih ada perdebatan apakah penggunaan alamat virtual office dapat digunakan sebagai tempat kedudukan suatu perusahaan. Dalam pengurusan izin usaha, surat keterangan domisili sangat dibutuhkan, termasuk juga dalam pendaftaran perusahaan. Surat keterangan domisili juga sangat diperlukan bagi perusahaan yang menerbitkan faktur pajak. Pengusaha kena pajak yang telah memiliki omzet mencapai Rp 600.000.000,00 akan disurvei oleh Dirjen pajak. sehingga penggunaan domisili virtual office tidak diperbolehkan bagi pengusaha tersebut.

Pengujian legalitas penggunaan virtual office oleh advokat sebagai kantor hukum dapat ditinjau dari beberapa aspek, yakni legalitas advokat dan dari bentuk hukum kantor advokat. Legalitas advokat melekat pada dirinya sendiri. Hal tersebut dapat dilihat dari persyaratan sebagai advokat sebagaimana diatur dalam Pasal 3 Undang-Undang Nomor 18 Tahun 2003 tentang Advokat. $^{14}$ Persyaratan untuk menjadi advokat hanya mengatur mengenai hal-hal yang terkait dengan kualifikasi seorang advokat sebagai sebuah profesi yakni dilihat dari segi kewarganegaraan,

14 Pasal 3 (1) Undang-undang Nomor 18 Tahun 2003 tentang Advokat menyatakan sebagai berikut

(1) Untuk dapat diangkat menjadi Advokat harus memenuhi persyaratan sebagai berikut :

a. warga negara Republik Indonesia;

b. bertempat tinggal di Indonesia;

c. tidak berstatus sebagai pegawai negeri atau pejabat negara;

d. berusia sekurang-kurangnya 25 (dua puluh lima) tahun;

e. berijazah sarjana yang berlatar belakang pendidikan tinggi hukum sebagaimana dimaksud dalam Pasal 2 ayat (1);

f. lulus ujian yang diadakan oleh Organisasi Advokat;

g. magang sekurang-kurangnya 2 (dua) tahun terus menerus pada kantor Advokat;

h. tidak pernah dipidana karena melakukan tindak pidana kejahatan yang diancam dengan pidana penjara 5 (lima) tahun atau lebih;

i. berperilaku baik, jujur, bertanggung jawab, adil, dan mempunyai integritas yang tinggi. 
tempat tinggal, status pekerjaan, usia, kualifikasi pendidikan, dan perilaku calon advokat. Dalam Undang-Undang tentang Advokat tersebut tidak mengatur mengenai ketentuan kantor advokat. Terkait dengan masalah perizinan, izin profesi tersebut merupakan izin yang terikat pada perorangan, bukan pada bentuk badan usahanya, sehingga kantor advokat tersebut tidak memerlukan berkas perizinan seperti Surat Izin Usaha Perdagangan dan Tanda Daftar Perusahan.

Bentuk badan usaha kantor advokat adalah firma. Firma adalah suatu jenis persekutuan perdata atau usaha bersama untuk menjalankan perusahaan yang didirikan dengan menggunakan nama bersama dari mereka yang ikut serta dalam firma tersebut. ${ }^{15}$ Dasar hukum firma diatur dalam Pasal 16 sampai $35 \mathrm{KUH}$ Dagang. Dalam Undang-Undang tentang advokat tidak ditentukan mengenai larangan penggunaan virtual office. Mengenai kantor advokat, dalam Pasal 8 butir c Kode Etik Advokat Indonesia dinyatakan "Kantor Advokat atau cabangnya tidak dibenarkan diadakan di suatu tempat yang dapat merugikan kedudukan dan martabat Advokat." Penggunaan virtual office sebagai kantor advokat tidak merugikan kedudukan dan martabat Advokat. Fasilitas yang disediakan oleh pemilik virtual office

15 Zaeny Asyhadie, 2008, Hukum Bisnis: Prinsip dan Pelaksanaannya di Indonesia, Rajawali, Jakarta, hlm. 37. justru meningkatkan prestise advokat dalam memberikan jasa hukum. Advokat dapat memanfaatkan semua fasilitas virtual office secara terjadwal dengan biaya sewa yang relative murah dibandingkan dengan membuat kantor sendiri.

Sebagai sebuah bentuk usaha firma, maka advokat tidak membutuhkan izin usaha sebagaimana layaknya badan usaha yang berbadan hukum. Hal ini memudahkan advokat untuk menggunakan alamat virtual office sebagai domisili. Tempat tinggal atau domisili merupakan tempat untuk melakukan perbuatan hukum. Tujuan dari penentuan domisili adalah untuk memudahkan para pihak untuk melakukan hubungan hukum, yakni suatu perbuatan hukum yang menimbulkan akibat hukum. ${ }^{16}$ Domisili pilihan diatur dalam Pasal 24 KUH Perdata yang menyatakan sebagai berikut:

Dalam suatu akta dan terhadap suatu soal tertentu, kedua pihak atau salah satu pihak bebas untuk memilih tempat tinggal yang lain daripada tempat tinggal yang sebenarnya. Pemilihan itu dapat dilakukan secara mutlak, bahkan sampai meliputi pelaksanaan keputusan hakim, atau dapat dibatasi sedemikian rupa sebagaimana dikehendaki oleh kedua pihak atau salah satu pihak. Dalam hal ini surat-surat juru sita, gugatangugatan atau tuntutan-tuntutan yang

16 Titik Triwulan Tutik, 2011, Hukum Perdata dalam Sistem Hukum Nasional, Kencana Prenada Media Group, Jakarta, hlm. 58. 
tercantum atau termaksud dalam akta itu, boleh dilakukan di tempat tinggal yang dipilih dan di muka hakim tempat tinggal itu.

Penggunaan alamat virtual office sebagai domisili kantor virtual office tidak menyalahi aturan hukum. Domisili bagi sebuah kantor advokat sangat penting mengingat tempat kedudukan tersebut memiliki berbagai manfaat baik manfaat praktik maupun manfaat yang dapa ditinjau dari segi hukum. Lokasi kantor advokat yang strategisakanmemudahkanmasyarakat untuk mengetahui kantor advokat yang dapat membantu mereka untuk menyelesaikan permasalahan hukum. Pemilihan lokasi kantor advokat dengan menyewa virtual office dapat menghindarkan advokat dari ketentuan zonasi ruang usaha. Kantor advokat menjadi pusat kegiatan bagi advokat untuk memberikan konsultasi hukum, melakukan negosiasi, pengarsipan dan sebagainya.

Dalam kajian hukum, tempat kedudukan kantor advokat sangat penting, karena kantor advokat dapat menjadi domisili pilihan bagi klien yang tidak menginginkan penggunaan tempat tinggalnya sebagai domisili. Dalam menentukan domisili pilihan, setidaknya ada empat hal yang perlu diperhatikan yakni:

a. Pilihan harus terjadi dengan adanya perjanjian.

b. Perjanjian dibuat dalam bentuk tertulis. c. Pohan hanya dapat terjadi untuk satu kali atau lebih perbuatan hukum atau hubungan hukum tertentu.

d. Penentuan pilihan tersebut disebabkan karena adanya kepentingan yang wajar. ${ }^{17}$

Penggunaan tempat kedudukan advokat sebagai domisili dari klien ditegaskan dalam surat kuasa khusus yang diberikan klien kepada advokat untuk mengurus perkaranya atau ditegaskan dalam identitas subjek hukum pada suatu perjanjian. Penegasan pilihan tersebut tidak boleh hanya dilakukan dengan lisan, melainkan harus dituangkan pada perjanjian tertulis mengenai hal tertentu berdasarkan kepentingan yang wajar.

\section{KESIMPULAN}

1. Hubungan hukum antara pemilik virtual office dengan advokat yang menggunakan virtual office sebagai kantor advokat adalah hubungan hukum berdasarkan perjanjian sewamenyewa. Pemilik virtual office berkedudukan sebagai pihak yang menyewakan, sedangkan advokat berkedudukan sebagai pihak penyewa. Hubungan hukum tersebut dituangkan dalam perjanjian tertulis.

2. Tempat kedudukan virtual office dapat menjadi tempat kedudukan kantoradvokatkarenapersyaratan

$17 \quad$ Ibid.., hlm. 62. 
untuk menjadi seorang advokat melekat pada individu, bukan pada jenis usaha dan bentuk usaha pelayanan hukum. Kantor advokat berbentuk firma, oleh sebab itu kantor advokat tidak membutuhkan izin usaha sebagaimana badan usaha yang berbadan hukum lainnya.

\section{DAFTAR PUSTAKA}

Abdulkadir Muhammad, 2014, Hukum Perdata Indonesia, Citra Additya Bakti, Bandung.

Atmadja, I Dewa Gede, 2010, Hukum

Konstitusi Problematika

Konstitusi Indonesia Sesudah

Perubahan UUD 1945, Setara

Press, Malang.

Bambang Sunggono, 1997, Metodologi

Penelitian Hukum, Raja Grafindo

Persada, Jakarta.

Handri Raharjo, 2009, Hukum Perjanjian di Indonesia, Buku Kita, Jakarta.

Johannes Ibrahim danLindawaty Sewu, 2007, Hukum Bisnis Dalam Persepsi Manusia Modern, Refika Aditama, Bandung.

Mukti Fajar dan Yulianto Achmad, 2010, Dualisme Penelitian Hukum Normatif dan Empiris, Pustaka Pelajar, Yogyakarta.

Munir Fuady, 2014, Konsep Hukum Perdata, Rajawali, Jakarta.

Salim HS, H. Abdullah dan Wiwiek Wahyuningsih, 2008, Perancangan Kontrak \& Memorandum of Understanding
$(M o U)$, Sinar Grafika, Jakarta.

Titik Triwulan Tutik, 2011, Hukum Perdata dalam Sistem Hukum Nasional, Kencana Prenada Media Group, Jakarta.

Zaeny Asyhadie, 2008, Hukum Bisnis:

Prinsip dan Pelaksanaannya di Indonesia, Rajawali, Jakarta.

Undang-Undang Nomor 18 Tahun 2003 tentang Advokat (Lembaran Negara Republik Indonesia Tahun 2003 Nomor 49. Tambahan Lembaran Negara Republik Indonesia Nomor 4288).

Basuki Winoto, 2015, Integrasi Aplikasi Kolaborasi Untuk Kantor Virtual, Prosiding Seminar Nasional Aplikasi Teknologi Informasi 2005 (SNATI 2005), Yogyakarta, 18 Juni 2005.

Franciscus Xaverius Raditya Wicaksono, 2014, Penegakan Kode Etik Profesi Advokat dalam Pendampingan Klien Perkara Pidana Korupsi, Jurnal Hukum Fakultas Hukum Universitas Atma Jaya Yogyakarta, Yogyakarta.

Sahuri Lasmadi, 2014, Peran Advokat salam Pendampingan Hukum, Jurnal Inovatif, Volume VII Nomor II Mei 2014, Jambi. 